Yet in the absence of such an understanding, agreement will not be possible or, worse, will be reached and then broken.

Another urgent need is for an open recognition that effective strategic arms control is necessarily a slow process. At any time, such as now, it is usually possible to distinguish between the steps that logically come next and those that can only follow. Mr Gorbachev's proposals earlier this year differ from previous versions in their open recognition of this truth. And in spite of the coolness with which some have greeted them, it is plain that they are also negotiable proposals. Why not at least find out, by attempting to negotiate on them?

\section{Nuclear virulence}

\section{Some of the problems of the nuclear industry are illustrated by a book review this week.}

NuCLEAR engineers, others who work in the nuclear industry and, indeed, those who use electricity as a fuel, should take care to read the book review by David Pearce, professor of economics at University College London, which appears on page 403 of this issue. To profit from the exercise, it is not necessary to agree with Pearce, or with the author of the book he is reviewing, both of whom are saying that civil nuclear power in Britain and probably elsewhere is a deception practised on an innocent public and on gullible politicians by a bunch of 1950 s scientists and technologists ignorant of the imperatives of the social sciences and incompetent as well. The benefit will be the better understanding of the obstacles that will have to be faced by those who would both breathe new life into national nuclear programmes that have fallen on bad times, or who would ensure improved public safety by the better management of nuclear plants.

Do-gooders of that kind should be the first to know what lies ahead of them, to which end Pearce should be generously forgiven his restraint, despite which his piece of action writing is as salutary a warning as there could be against all things nuclear. That the British decision to build advanced gascooled reactors in succession to the first generation of natural uranium reactors turned out to be economically unwise is now well-documented, but he does not need, with the passage of so much time, to spare the blushes of those who took the decision, and who are now mostly dead in any case, by concealing the explanation. The decision was technically unsound and was widely said to be so at the time. The problem, in 1960 or thereabouts, was that people were faced with the familiar problem of not knowing how far ahead to jump in the development of a novel technology. The besetting British sin is to jump too far (with the first supersonic civil airliners and so on), but on this occasion they erred in the other direction.

Pearce is also overkind to British nuclear engineers in ascribing the concealment of the truth about nuclear energy to the cover-up engineers who work in public relations and for lobbying organizations. Why not tell it like it was (and, perhaps, still is) that the founders of the British nuclear industry were woefully ignorant of the basic parameters of their craft, the need to anneal irradiated graphite, the corrosion of magnesium by carbon dioxide and the embrittlement of steel by helium gas, all of which they should have learned about at school (together with the biological effects of ingested plutonium)? But his echo of the contention that the problem of waste management must be "solved" before civil nuclear power is exploited cannot of course be gainsaid, although it would have been helpful to have had an economist's view of what constitutes a solution to such a problem.

What Pearce has done is to provide a vivid illustration of the depth of feeling, even passion, that now attends the nuclear issue even in previously sleepy places such as Britain. Many will be grateful to him, especially those who manage without electricity.

\section{Good luck strikes back}

British astronomers should move their surplus observatory to a university.

LoNG delayed decisions become palatable because those most affected by them have been anaesthetized while waiting. This is probably why British astronomers appear unperturbed by the announcement last week that the Royal Greenwich Observatory ( $\mathrm{RGO}$ ), founded as an applied science laboratory to exploit seventeenth-century astronomy for better navigation and which left the site whose name it bears nearly forty years ago, is once again to move, perhaps even to merge with the Royal Observatory, Edinburgh. British astronomers are now thoroughly used to the notion that support services for astronomy must be reduced. As one distinguished committee after another has failed to reach a firm conclusion, the exasperated victims have often been chief among those pleading with the executioner to get on with his task.

On this occasion, remarkably, the need that something should be done is not a mark of failure, recklessness or the lack of funds, but if anything the opposite on all three counts. For the best part of fifteen years, or at least ten, the Science and Engineering Research Council (SERC) has dealt imaginatively, responsibly and generously with optical and nearoptical astronomy. Capital investment in new telescopes runs close to $£ 50$ million, and there is a substantial community of professional astronomers fighting for time on this equipment. One measure of quality of the equipment available to British astronomers is that a SERC committee seriously considered, a year ago, the abandonment of the excellent partnership with Australia in the Anglo-Australian telescope. The two Britishbased observatories, meanwhile, have found their usefulness diminish. Each of them has provided important support for the building of the new telescopes, but it has been plain for years that there would be no need for both of them when that work was done, as it will be long before 1990 .

Two questions arise, only one of which is of a muck-raking character. Most of the decisions about the construction of new telescopes were taken a decade or more ago, when public funds, although already constrained, were easier to come by than at present. In the past few years, the climate has changed so much that it is unthinkable that the same decisions would be taken now; British astronomers are lucky to have squeezed in under the wire in this way.

So why has there been such diffidence in deciding what to do about RGO? And although SERC has laid down that the move of RGO from its present cloudy site must be "selffinancing", why is nothing said about the financial savings that may flow from the decision that RGO should move? If there are none, people will be asking whether the move can be worthwhile.

The second question is raised by the incompleteness of last week's decision. RGO is to move, but will be told only in June where and with whom it will spend the rest of its days. SERC seems to be faced with two choices. A merger of the two ground-based observatories would yield economies of scale and concentration, but SERC judges that an institution based in Edinburgh could not have the close links with academic astronomers that would be fruitful for both sides. This is the spirit in which the research council has invited "expressions of interest" (otherwise known as bids) from universities willing to take in RGO as a kind of paying guest. Cambridge and Manchester are the chief contenders. It should be plain to SERC that the benefits of an academic partnership are huge, and that the university option provides British research institutes with a chance to give back to British universities some of the resources and responsibility of which they have been robbed over the decades. But would it not be invidious to pick one out of two? Maybe, but to settle for a merger would be wrong. 